\title{
HEPATITIS B e ANTIGEN AND THE RISK OF HEPATOCELLULAR CARCINOMA
}

\author{
Hwal-I Yang, M.Sc., Sheng-Nan Lu, M.D., Ph.D., Yun-Fan Liaw, M.D., San-Lin You, Ph.D., Chien-An Sun, Sc.D., \\ Li-Yu Wang, Ph.D., Chuhsing K. Hsiao, Ph.D., Pei-Jer Chen, M.D., Ph.D., Ding-Shinn Chen, M.D., \\ and Chien-Jen Chen, Sc.D., for the Taiwan Community-Based Cancer Screening Project Group*
}

\begin{abstract}
Background The presence of hepatitis B e antigen ( $\mathrm{HBeAg})$ in serum indicates active viral replication in hepatocytes. HBeAg is thus a surrogate marker for the presence of hepatitis B virus DNA. We conducted a prospective study to determine the relation between positivity for hepatitis B surface antigen (HBsAg) and $\mathrm{HBeAg}$ and the development of hepatocellular carcinoma.

Methods In 1991 and 1992, we enrolled 11,893 men without evidence of hepatocellular carcinoma (age range, 30 to 65 years) from seven townships in Taiwan. Serum samples obtained at the time of enrollment were tested for HBsAg and $\mathrm{HBeAg}$ by radioimmunoassay. The diagnosis of hepatocellular carcinoma was ascertained through data linkage with the computerized National Cancer Registry in Taiwan and with death certificates. We performed a multiple regression analysis to determine the relative risk of hepatocellular carcinoma among men who were positive for $\mathrm{HBsAg}$ alone or for $\mathrm{HBsAg}$ and $\mathrm{HBeAg}$, as compared with those who were negative for both.

Results There were 111 cases of newly diagnosed hepatocellular carcinoma during 92,359 person-years of follow-up. The incidence rate of hepatocellular carcinoma was 1169 cases per 100,000 person-years among men who were positive for both HBsAg and $\mathrm{HBeAg}, 324$ per 100,000 person-years for those who were positive for HBsAg only, and 39 per 100,000 person-years for those who were negative for both. After adjustment for age, sex, the presence or absence of antibodies against hepatitis $C$ virus, cigarette-smoking status, and use or nonuse of alcohol, the relative risk of hepatocellular carcinoma was 9.6 (95 percent confidence interval, 6.0 to 15.2) among men who were positive for HBsAg alone and 60.2 (95 percent confidence interval, 35.5 to 102.1) among those who were positive for both $\mathrm{HBsAg}$ and $\mathrm{HBeAg}$, as compared with men who were negative for both.

Conclusions Positivity for $\mathrm{HBeAg}$ is associated with an increased risk of hepatocellular carcinoma. (N Engl J Med 2002;347:168-74.)

Copyright $\odot 2002$ Massachusetts Medical Society.
\end{abstract}

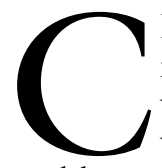

HRONIC hepatitis B virus (HBV) infection is a serious clinical problem because of its worldwide distribution and potential for adverse sequelae, including hepatic cirrhosis and hepatocellular carcinoma. It is particularly prevalent in the Asian-Pacific region, where patients usually acquire the infection at the time of birth or in early childhood.

The natural course of chronic HBV infection acquired early in life can be divided into three phases., ${ }^{1,2}$ The first phase is characterized by active replication of $\mathrm{HBV}$, positivity for hepatitis B e antigen ( $\mathrm{HBeAg}$ ), and normal-to-low levels of serum aspartate aminotransferase and alanine aminotransferase. The second phase, characterized by immune clearance, usually occurs from the age of 15 to 35 years, during which hepatitis flares may occur as the result of specific, T-lymphocyte-mediated cellular responses to viral antigens and apoptosis of hepatocytes. This phase subsides as viral replication declines, with the appearance of antibodies against $\mathrm{HBeAg}$ and clinical remission. In the third, or residual, phase, patients are positive for hepatitis B surface antigen (HBsAg) and negative for $\mathrm{HBeAg}$, and they do not have active liver disease. ${ }^{1,2}$ Epidemiologic studies have shown that positivity for $\mathrm{HBsAg}$ is one of the most important risk factors for hepatocellular carcinoma. ${ }^{3-5}$

Positivity for $\mathrm{HBeAg}$ usually indicates active replication of HBV. Loss of detectable $\mathrm{HBeAg}$, together with the emergence of antibodies against $\mathrm{HBeAg}$, has been used as a key end point in studies of the efficacy of various agents, including lamivudine and interferon, for the treatment of chronic hepatitis B. ${ }^{6,7}$ However, the role of positivity for $\mathrm{HBeAg}$ in the prediction of hepatocellular carcinoma remains inconclusive. Various studies of case series have found that the prevalence of HBeAg was lowest among patients with hepatocel-

From the Graduate Institute of Epidemiology, College of Public Health, National Taiwan University, Taipei (H.-I.Y., S.-L.Y., C.K.H., C.-J.C.); the Department of Gastroenterology, Kaohsiung Chang-Gung Memorial Hospital, Kaohsiung (S.-N.L.); Chang-Gung Memorial Hospital and ChangGung University, Taoyuan (Y.-F.L.); the Department of Public Health, National Defense Medical Center, Taipei (C.-A.S.); the Graduate Institute of Aboriginal Health, Tzu Chi University, Hualien (L.-Y.W.); and the Liver Research Unit and Hepatitis Research Center, National Taiwan University Hospital (P.-J.C., D.-S.C.) - all in Taiwan. Address reprint requests to Dr. ChienJen Chen at the College of Public Health, National Taiwan University, 1 Jen-Ai Rd., Section 1, Taipei 10018, Taiwan, or at cjchen@ha.mc.ntu.edu.tw.

*Other members of the Taiwan Community-Based Cancer Screening Project Group are listed in the Appendix.

168 • N Engl J Med, Vol. 347, No. 3 • July 18, 2002 • www.nejm.org 
lular carcinoma, highest among patients with chronic hepatitis $\mathrm{B}$, and intermediate among those with liver cirrhosis. ${ }^{8,9}$ In several case-control studies, however, the prevalence of $\mathrm{HBeAg}$ was significantly higher among HBsAg-positive patients with hepatocellular carcinoma than among matched HBsAg-positive controls. ${ }^{10-14}$ All these studies were cross-sectional in design, with disease status and the prevalence of antigen positivity determined at the same time. The studies did not determine whether positivity for $\mathrm{HBeAg}$ preceded the onset of hepatocellular carcinoma. We conducted a prospective study of the relation between positivity for $\mathrm{HBeAg}$ and the risk of hepatocellular carcinoma among 11,893 men in Taiwan.

\section{METHODS}

\section{Study Cohort}

From 1991 to 1992, we invited all 47,079 men between the ages of 30 and 65 years who were living in seven townships in Taiwan to participate in the study; the men were contacted by mail. A total of 11,893 men ( 25 percent) agreed to participate. Each subject provided written informed consent for us to conduct an interview, collect a blood specimen, and perform various serologic and biochemical assays. The study was conducted between February 1991 and September 2000.

\section{Data Collection and Blood Tests}

All the men were interviewed in person with the use of a structured questionnaire administered by well-trained public health nurses. The men were questioned about sociodemographic characteristics, diet, cigarette smoking, consumption of alcohol, betel-nut chewing, their medical and surgical history, and any family history of hepatocellular carcinoma or liver cirrhosis. A 10-ml specimen of blood was collected with the use of a disposable vacuum syringe. Samples of serum separated on the day of blood collection were kept in a freezer $\left(\right.$ at $\left.-70^{\circ} \mathrm{C}\right)$ until they were assayed. The specimens were tested at the time of enrollment for HBsAg and $\mathrm{HBeAg}$ by radioimmunoassay with the use of a commercial kit (Abbott Laboratories) and were tested for antibodies against hepatitis $\mathrm{C}$ virus by enzyme immunoassay with the use of a second-generation commercial kit (Abbott Laboratories).

For men in whom hepatocellular carcinoma was diagnosed during follow-up who were positive for HBsAg and negative for HBeAg at enrollment, tests for antibodies against HBeAg and HBV DNA in serum samples obtained at the time of enrollment were performed in 2002 as part of a nested case-control substudy. For each man with hepatocellular carcinoma, we identified two healthy controls matched for age, date of enrollment, and township, except that for each of two men with hepatocellular carcinoma, there was only one matched control for whom frozen serum samples were available. Thus, frozen serum samples collected at the time of enrollment were available for a total of 44 men with hepatocellular carcinoma and 86 matched controls who were positive for HBsAg and negative for $\mathrm{HBeAg}$. These samples were tested for antibodies against $\mathrm{HBeAg}$ with the use of an enzyme-linked immunoassay (Abbott Laboratories) and were tested for HBV DNA with the use of a branched-chain DNA assay (Quantiplex, Chiron), according to the manufacturer's instructions. The threshold of detection for the quantitative assay of DNA was 2.5 pg per milliliter.

\section{Follow-up for Hepatocellular Carcinoma}

In Taiwan, interferon, lamivudine, or other antiviral or immune therapy was rarely used to treat chronic hepatitis B before 2001 . The Bureau of National Health Insurance in Taiwan did not provide reimbursement for the cost of treatment with lamivudine until March 2001. Since treatment with interferon alfa is expensive and has severe side effects that make it difficult to tolerate, the Bureau of National Health Insurance only recently began to provide reimbursement for the cost of this treatment. Other antiviral or immune therapies are also rarely used to treat chronic hepatitis B in Taiwan. For these reasons, we did not refer our subjects with chronic hepatitis B to the hospital for treatment after enrollment.

At the time of enrollment, none of the men had known hepatocellular carcinoma on the basis of screening tests (abdominal ultrasonography and serologic tests), interviews, and the absence of linkage with the National Cancer Registry. Cases of hepatocellular carcinoma were ascertained by computerized linkage of data with information from the National Cancer Registry in Taiwan for the period from January 1, 1984, through September 30, 2000. In addition, we linked data with information from death certificates to identify deaths from cases of hepatocellular carcinoma that were not included in the National Cancer Registry. The diagnosis was based on pathological examination in 56 men and on the results of abdominal ultrasonographic, angiographic, or computed tomographic studies combined with an elevated serum alpha-fetoprotein level $\left(\geqslant 400 \mathrm{ng}\right.$ per milliliter) in 55 men. ${ }^{10-13}$

\section{Statistical Analysis}

The person-years of follow-up for each subject were calculated from the date of enrollment to the date of the diagnosis of newly developed hepatocellular carcinoma, the date of death, or the date of the last link to data from the National Cancer Registry (September 30,2000 ), whichever came first. Incidence rates were calculated by dividing the number of incident cases of hepatocellular carcinoma by the number of person-years of follow-up. Data for men in whom hepatocellular carcinoma was not diagnosed were censored at the date of death or the last date of follow-up (September 30, 2000). A Cox's proportional-hazards model was used to estimate the relative risk of hepatocellular carcinoma associated with positivity for HBsAg and HBeAg and other risk factors, including advanced age, positivity for antibodies against hepatitis $\mathrm{C}$ virus, cigarette smoking, and consumption of alcohol. The 95 percent confidence intervals for the relative risks were also calculated. Significance levels were determined with the use of two-tailed tests. The cumulative incidence of hepatocellular carcinoma was calculated for men who were negative for both $\mathrm{HBsAg}$ and $\mathrm{HBeAg}$, those who were positive for HBsAg alone, and those who were positive for both HBsAg and $\mathrm{HBeAg}$, with the use of the Nelson-Aalen method (a nonparametric method for estimating the cumulative hazard). ${ }^{15-17}$ For the 130 men included in the nested case-control substudy described above, we used logistic-regression analysis to determine the association between the level of HBV DNA and hepatocellular carcinoma. Statistical analysis was performed with Stata software (Stata).

\section{RESULTS}

The prevalence of HBsAg among all men and the prevalence of $\mathrm{HBeAg}$ among those who were positive for HBsAg are shown in Table 1 according to age, cigarette-smoking status, and use or nonuse of alcohol. The older the age, the lower the prevalence of HBsAg and $\mathrm{HBeAg}$. The prevalence was consistent with the rates reported previously in Taiwan., ${ }^{1,2}$ Thus, we considered the study cohort to be representative of the general population of Taiwanese men in terms of the prevalence of HBsAg and HBeAg.

Men who smoked and those who drank alcohol had a lower prevalence of HBsAg alone but a higher prevalence of $\mathrm{HBeAg}$ among those who were positive for HBsAg than did nonsmokers and nondrinkers. But 
Table 1. Prevalence of Hepatitis B Surface Antigen (HBsag) and Hepatitis B e Antigen (HBeAg) in 11,893 Men in Taiwan.

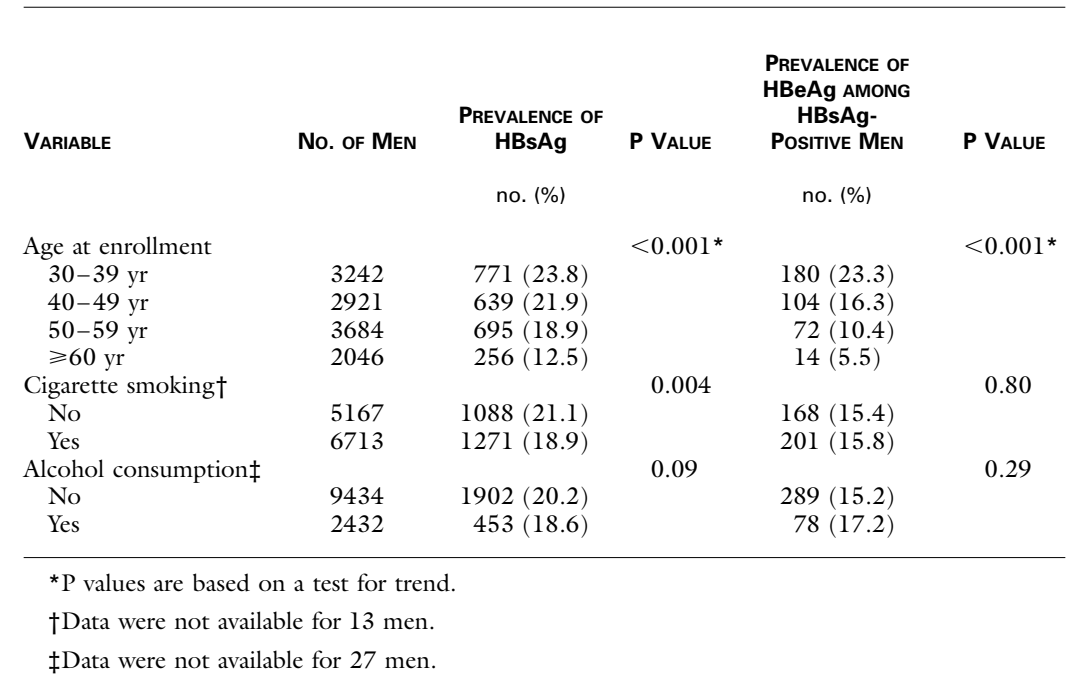

the difference was statistically significant only for the prevalence of HBsAg alone among cigarette smokers and nonsmokers. Age and cigarette-smoking status differed significantly among the men who were negative for both $\mathrm{HBsAg}$ and $\mathrm{HBeAg}$, those who were positive only for HBsAg, and those who were positive for both HBsAg and HBeAg $(\mathrm{P}<0.001$ and $\mathrm{P}=0.02$, respectively). The rates of use and nonuse of alcohol were similar in the three groups of men $(\mathrm{P}=0.14)$.

A total of 111 cases of hepatocellular carcinoma were diagnosed during a follow-up period of 92,359 person-years; the overall incidence rate was 120.2 cases per 100,000 person-years. The incidence rate was 39.1 among men who were negative for both HBsAg and $\mathrm{HBeAg}, 324.3$ among those who were positive only for HBsAg, and 1169.4 among those who were positive for both HBsAg and HBeAg (Table 2). The prevalence of HBeAg was 39 percent among the men who were positive for HBsAg. The cumulative incidence of hepatocellular carcinoma is shown in Figure 1 for the three groups. The men who were positive for both HBsAg and HBeAg had a much higher cumulative incidence of hepatocellular carcinoma than those who were positive only for HBsAg and an even higher incidence than those who were negative for both $(\mathrm{P}<$ 0.001 for both comparisons). The longer the followup, the greater the differences among the three groups.

Table 3 shows the results of the multiple-regression analysis with the use of the Cox proportional-hazards model. After adjustment for other risk factors, the relative risk of hepatocellular carcinoma was 9.6 (95 percent confidence interval, 6.0 to 15.2) for men who were positive for HBsAg alone and 60.2 (95 percent confidence interval, 35.5 to 102.1 ) for those who were positive for both $\mathrm{HBsAg}$ and $\mathrm{HBeAg}$, as compared with men who were negative for both. An older age at the time of enrollment, the presence of antibodies against hepatitis $\mathrm{C}$ virus, cigarette smoking, and consumption of alcohol were also associated with an increased risk of hepatocellular carcinoma. The findings were similar when the data were stratified according to age, cigarette-smoking status, and use or nonuse of alcohol, in an analysis adjusted for other risk factors (Table 4).

In the nested case-control analysis that involved 130 men who were positive for HBsAg and negative for HBeAg (44 men with newly diagnosed hepatocellular carcinoma and 86 matched controls), 120 men (92 percent) were positive for antibodies against $\mathrm{HBeAg}$, and 29 (22 percent) were positive for $\mathrm{HBV}$ DNA. The proportion of men who were positive for antibodies against $\mathrm{HBeAg}$ did not differ significantly between men with hepatocellular carcinoma and controls $(\mathrm{P}=0.16)$. Seventeen men with hepatocellular carcinoma (39 percent) and 12 controls (14 percent) had detectable serum levels of HBV DNA $(>2.5 \mathrm{pg}$ per milliliter). The odds ratio for the development of hepatocellular carcinoma was 3.9 (95 percent confidence interval, 1.6 to 9.2) for men who had detectable HBV DNA, as compared with those who had undetectable levels. The odds ratio increased with increases in the level of HBV DNA (Table 5).

\section{DISCUSSION}

It has been reported that in most patients with hepatocellular carcinoma, the disease develops after the

170 - N Engl J Med, Vol. 347, No. 3 • July 18, $2002 \cdot$ www.nejm.org 
Table 2. Incidence of Hepatocellular Carcinoma during Follow-up. *

\begin{tabular}{|c|c|c|c|c|}
\hline $\begin{array}{l}\text { Results of } \\
\text { HBV ANTIGEN TESTS }\end{array}$ & $\begin{array}{l}\text { PeRson-YR OF } \\
\text { FolLOW-UP }\end{array}$ & $\begin{array}{l}\text { No. of } \\
\text { MEN }\end{array}$ & $\begin{array}{l}\text { No. of Cases of } \\
\text { Hepatocellular } \\
\text { Carcinoma }\end{array}$ & $\begin{array}{l}\text { INCIDENCE RATE } \\
(95 \% \mathrm{Cl})\end{array}$ \\
\hline & & & & cases $/ 100,000$ person-yr \\
\hline $\begin{array}{l}\text { Negative for HBsAg } \\
\text { and } \mathrm{HBeAg}\end{array}$ & 74,205 & 9532 & 29 & $39.1(26.2-56.1)$ \\
\hline $\begin{array}{l}\text { Positive for } \mathrm{HBsAg}, \\
\text { negative for HBeAg }\end{array}$ & 15,418 & 1991 & 50 & $324.3(240.7-427.5)$ \\
\hline $\begin{array}{l}\text { Positive for } \mathrm{HBsAg} \\
\text { and } \mathrm{HBeAg}\end{array}$ & 2,736 & 370 & 32 & $1169.4(799.9-1650.9)$ \\
\hline
\end{tabular}

${ }^{*} \mathrm{HBV}$ denotes hepatitis B virus, CI confidence interval, HBsAg hepatitis B surface antigen, and HBeAg hepatitis B e antigen.

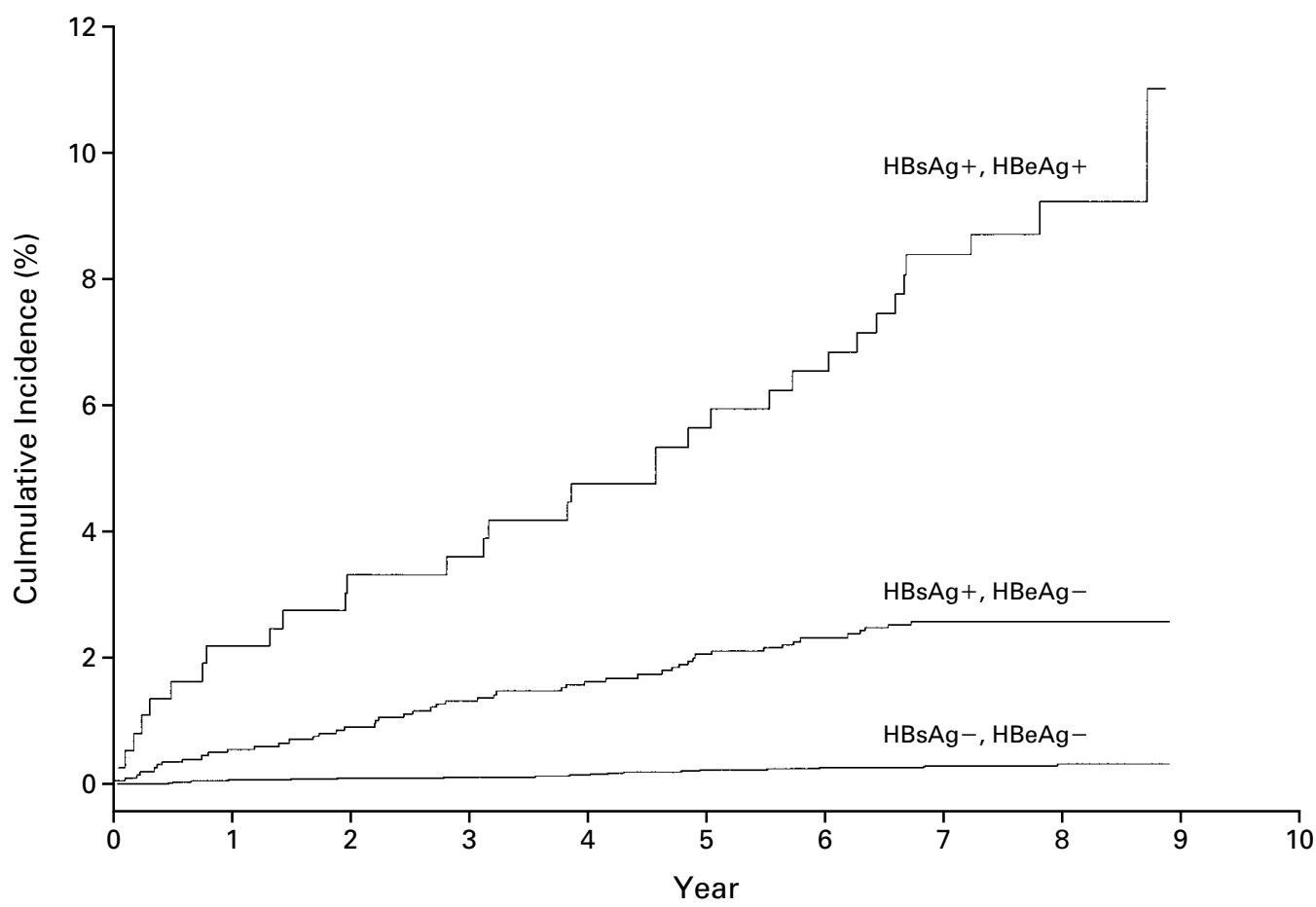

Figure 1. Cumulative Incidence of Hepatocellular Carcinoma during Follow-up among 11,893 Men in Taiwan, According to the Presence or Absence of Hepatitis B Surface Antigen (HBsAg) and Hepatitis B e Antigen (HBeAg) at Enrollment.

The cumulative incidence was estimated with the use of the Nelson-Aalen method.

development of antibodies against HBeAg. ${ }^{18}$ In our follow-up study, with all blood samples collected and assayed before the diagnosis of hepatocellular carcinoma, the prevalence of $\mathrm{HBeAg}$ was 39 percent among men who were positive for HBsAg at the time of enrollment and who subsequently received a diagnosis of hepatocellular carcinoma - a much higher prevalence than that reported in a previous case-series study
(18 percent $)^{9}$ and in previous case-control studies ( 22 and 25 percent). ${ }^{12,14}$ Similarly, in our study, the relative risks of hepatocellular carcinoma among men who were positive for HBsAg alone (9.6) and among those who were positive for both $\mathrm{HBsAg}$ and $\mathrm{HBeAg}$ (60.2), as compared with men who were negative for both, were much higher than in previous case-control studies. ${ }^{10-14}$ 
Table 3. Adjusted Relative Risk of Hepatocellular Carcinoma According to Various Risk Factors. *

\begin{tabular}{|c|c|c|}
\hline VARIABLE & $\begin{array}{l}\text { No. of Cases of } \\
\text { Hepatocellular } \\
\text { Carcinoma }\end{array}$ & $\begin{array}{l}\text { AdJusted } \\
\text { RELATIVE RISK } \\
(95 \% \mathrm{Cl})\end{array}$ \\
\hline \multicolumn{3}{|l|}{ Age at enrollment } \\
\hline $30-39 \mathrm{yr} \dagger$ & 6 & 1.0 \\
\hline $40-49 \mathrm{yr}$ & 23 & $5.4(2.2-13.2) \ddagger$ \\
\hline $50-59 \mathrm{yr}$ & 55 & $13.5(5.8-31.7) \ddagger$ \\
\hline$\geqslant 60 \mathrm{yr}$ & 27 & $17.7(7.1-43.9) \ddagger$ \\
\hline \multicolumn{3}{|c|}{ Results of HBV antigen tests } \\
\hline $\begin{array}{l}\text { Negative for HBsAg } \\
\text { and HBeAg } \dagger\end{array}$ & 29 & 1.0 \\
\hline $\begin{array}{l}\text { Positive for } \mathrm{HBsAg}, \\
\text { negative for } \mathrm{HBeAg}\end{array}$ & 50 & $9.6(6.0-15.2) \ddagger$ \\
\hline $\begin{array}{l}\text { Positive for } \mathrm{HBsAg} \\
\text { and } \mathrm{HBeAg}\end{array}$ & 32 & $60.2(35.5-102.1) \ddagger$ \\
\hline \multicolumn{3}{|c|}{ Antibodies against hepatitis $C$ virus } \\
\hline No† & 98 & 1.0 \\
\hline Yes & 13 & $2.7(1.5-4.9) \ddagger$ \\
\hline \multicolumn{3}{|l|}{ Cigarette smoking } \\
\hline No† & 41 & 1.0 \\
\hline Yes & 70 & $1.5(1.0-2.2) \S$ \\
\hline \multicolumn{3}{|l|}{ Alcohol consumption } \\
\hline Not & 80 & 1.0 \\
\hline Yes & 31 & $1.5(1.0-2.3) \S$ \\
\hline
\end{tabular}

*Data were not available on cigarette smoking for 13 men, on alcohol consumption for 27 , and on antibodies against hepatitis $\mathrm{C}$ virus for 77 . CI denotes confidence interval, HBV hepatitis B virus, HBsAg hepatitis B surface antigen, and HBeAg hepatitis B e antigen.

$\dagger$ This was the reference group.

$\ddagger \mathrm{P}<0.001$.

$\S \mathrm{P}=0.06$
Both indirect and direct carcinogenic mechanisms are involved in the pathogenesis of hepatocellular carcinoma induced by chronic HBV infection. ${ }^{19} \mathrm{HBV}$ may induce hepatocellular carcinoma indirectly by causing chronic necroinflammatory hepatic disease. ${ }^{20}$ When HBV replication is sustained, as indicated by positivity for $\mathrm{HBeAg}$, malignant transformation may occur as a result of continuous or recurrent cycles of hepatocyte necrosis and regeneration. The accelerated rate of cell turnover may act as a tumor promoter through the accumulation of spontaneous mutations or DNA damage caused by exogenous factors, resulting in an increased selective growth advantage for transformed cells. The accelerated turnover rate may also result in cleavage of viral DNA at specific motifs, resulting in linear DNA that is inserted into chromosomal DNA through increased intracellular topoisomerase I activity. ${ }^{21}$ Chronic necroinflammation may induce malignant transformation by generating $\mathrm{mu}^{-}$ tagenic reactive oxygen species during the inflammatory process. ${ }^{22}$

Active replication of $\mathrm{HBV}$ may also initiate malignant transformation through a direct carcinogenic mechanism by increasing the probability of insertion of viral DNA in or near proto-oncogenes, tumor-suppressor genes, or their regulatory elements of cellular DNA. ${ }^{23,24}$ The integration of viral DNA may increase the production of transactivator protein hepatitis $\mathrm{B}$ $\mathrm{X}$ antigen, which may induce the malignant transfor-

Table 4. Adjusted Relative Risk of Hepatocellular Carcinoma, with Stratification According to Age, Cigarette-Smoking Status, AND Use or Nonuse of AlCOHOL.

\begin{tabular}{|c|c|c|c|}
\hline \multirow[t]{2}{*}{ VARIABLE } & \multicolumn{3}{|c|}{ Adjusted Relative RisK $(95 \% \mathrm{Cl}) *$} \\
\hline & $\begin{array}{c}\text { NEGATIVE FOR } \\
\text { HBsAg AND HBeAg }\end{array}$ & $\begin{array}{l}\text { POSITIVE FOR HBsAg, } \\
\text { NEGATIVE FOR HBeAg }\end{array}$ & $\begin{array}{c}\text { POSITIVE FOR } \\
\text { HBsAg AND HBeAg }\end{array}$ \\
\hline \multicolumn{4}{|c|}{ Age at enrollment $\dagger$} \\
\hline$\leqslant 55 \mathrm{yr}$ & 1.0 & $6.1(3.3-11.4)$ & $25.4(13.3-48.6)$ \\
\hline$>55 \mathrm{yr}$ & 1.0 & $14.8(7.5-29.5)$ & $95.5(42.5-214.5)$ \\
\hline \multicolumn{4}{|c|}{ Cigarette smoking $\ddagger$} \\
\hline No & 1.0 & $14.3(6.1-33.8)$ & $67.0(26.1-171.7)$ \\
\hline Yes & 1.0 & $8.9(5.1-15.5)$ & $76.9(39.4-150.3)$ \\
\hline \multicolumn{4}{|c|}{ Alcohol consumption $\$$} \\
\hline No & 1.0 & $9.7(5.6-16.9)$ & $69.0(37.1-128.2)$ \\
\hline Yes & 1.0 & $11.4(5.0-26.3)$ & $52.1(18.0-150.8)$ \\
\hline \multicolumn{4}{|c|}{$\begin{array}{l}\text { *The reference group was the group of men who were negative for both hepatitis B surface antigen } \\
(\mathrm{HBsAg}) \text { and hepatitis B e antigen }(\mathrm{HBeAg}) \text {. CI denotes confidence interval. } \mathrm{P}<0.001 \text { for all com- } \\
\text { parisons. }\end{array}$} \\
\hline \multicolumn{4}{|c|}{$\begin{array}{l}\text { †The analysis was adjusted for the presence or absence of antibodies against hepatitis } \mathrm{C} \text { virus, cig- } \\
\text { arette-smoking status, and use or nonuse of alcohol. }\end{array}$} \\
\hline \multicolumn{4}{|c|}{$\begin{array}{l}\ddagger \text { The analysis was adjusted for age (as a continuous variable), the presence or absence of antibodies } \\
\text { against hepatitis } \mathrm{C} \text { virus, and use or nonuse of alcohol. }\end{array}$} \\
\hline
\end{tabular}

172 • N Engl J Med, Vol. 347, No. 3 • July 18, 2002 · www.nejm.org 
Table 5. Level of Hepatitis B Virus (HBV) DNA in Men with Hepatocellular Carcinoma and Matched Controls Who Were Positive for Hepatitis B Surface Antigen and Negative for Hepatitis B e Antigen at Enrollment.

\begin{tabular}{|c|c|c|c|}
\hline HBV DNA & $\begin{array}{c}\text { Men With } \\
\text { Hepatocellular } \\
\text { Carcinoma } \\
(\mathbf{N}=\mathbf{4 4 )}\end{array}$ & $\begin{array}{l}\text { Matched } \\
\text { Controls } \\
(\mathrm{N}=\mathbf{8 6})\end{array}$ & $\begin{array}{l}\text { ADJUSTED } \\
\text { ODDS RATIO } \\
\text { (95\% CI)* }\end{array}$ \\
\hline \multicolumn{4}{|c|}{ no. of men } \\
\hline Undetectable $(<2.5 \mathrm{pg} / \mathrm{ml}) \dagger$ & 27 & 74 & 1.0 \\
\hline $2.5-13.0 \mathrm{pg} / \mathrm{ml}$ & 7 & 7 & $2.3(0.7-7.3)$ \\
\hline$>13.0 \mathrm{pg} / \mathrm{ml}$ & 10 & 5 & $6.0(1.7-21.4) \ddagger$ \\
\hline
\end{tabular}

mation of hepatocytes, as well as bind to the p53 tumor-suppressor gene and disrupt its functions. ${ }^{25-30}$

The presence of antibodies against $\mathrm{HBeAg}$ has been used as an important marker for the resolution of active HBV infection and for a sustained response to treatment with lamivudine alone or in combination with interferon alfa. ${ }^{7}$ In the natural history of chronic hepatitis $\mathrm{B}$, the spontaneous or interferon alfainduced development of antibodies against $\mathrm{HBeAg}$ leads to improvement in the clinical outcome.6,31 One study showed that patients who had a response to treatment with interferon alfa (i.e., clearance of HBeAg) were much less likely to have major liver complications during a five-year period of follow-up than were treated or untreated patients with persistent HBeAg. ${ }^{31}$ A long-term controlled trial of treatment with interferon alfa showed that hepatocellular carcinoma developed more frequently in untreated patients than in treated patients and that it developed only in those with persistent $\mathrm{HBeAg} .{ }^{6}$ Our study showed that a negative test for $\mathrm{HBeAg}$ was associated with a low risk of hepatocellular carcinoma, suggesting that the earlier the development of antibodies against $\mathrm{HBeAg}$ occurs, the lower the risk of hepatocellular carcinoma.

We performed tests for HBsAg and HBeAg only at the time of enrollment. The effect of the appearance of antibodies against HBsAg and $\mathrm{HBeAg}$ on the development of hepatocellular carcinoma was not assessed. If the appearance of antibodies against $\mathrm{HBeAg}$ occurred after enrollment, the risk of hepatocellular carcinoma among men who were initially positive for $\mathrm{HBeAg}$ was underestimated. Tests for antibodies against $\mathrm{HBeAg}$ were not performed at the time of enrollment for men who were negative for HBeAg. However, we did perform tests for antibodies against
HBeAg and for HBV DNA in frozen serum samples collected at the time of enrollment from the 44 men in whom hepatocellular carcinoma was subsequently diagnosed and the 86 matched controls, all of whom were initially positive for $\mathrm{HBsAg}$ and negative for $\mathrm{HBeAg}$. In this nested case-control analysis, more than 90 percent of the men were positive for antibodies against $\mathrm{HBeAg}$, and there was no significant difference in this respect between the men with hepatocellular carcinoma and the controls. However, positivity for HBV DNA was associated with a significantly increased risk of hepatocellular carcinoma.

HBV DNA is found in most patients who are positive for $\mathrm{HBeAg}$, in a substantial proportion of those with antibodies against $\mathrm{HBeAg}$ (20 to 25 percent), and in some who are negative for $\mathrm{HBeAg}$. Therefore, HBV DNA is the most important predictor of the development of hepatocellular carcinoma in HBsAgpositive Taiwanese men. However, the assay for HBV DNA is expensive and is performed only at specialized laboratories, whereas the assays for $\mathrm{HBeAg}$, a surrogate marker of HBV DNA, and antibodies against $\mathrm{HBeAg}$ are inexpensive and are performed routinely. At present, a test for $\mathrm{HBeAg}$ may therefore be a more practical method for predicting the risk of hepatocellular carcinoma.

In conclusion, $\mathrm{HBeAg}$, in addition to $\mathrm{HBsAg}$, may be a useful marker of the risk of hepatocellular carcinoma. Persons considered to be at high risk because of positivity for $\mathrm{HBeAg}$ would be candidates for antiviral-drug treatment and close monitoring for the development of liver diseases associated with chronic HBV infection.

Supported by grants from the Department of Health, Executive Yuan, Taipei, Taiwan. 


\section{APPENDIX}

The following institutions and investigators, in addition to the authors, participated in the Taiwan Community-Based Cancer Screening Project Group: National Taiwan University Hospital - G.-T. Huang, H.-S. Lee, P.-M. Yang, C.-H. Chen; Huhsi Health Center, Penghu County-S.-C. Ho, T.-G. Lu; Provincial Penghu Hospital - W.-P. Wu, C.-T. Chen; Sanchi Health Center, Taipei County - C.-G. Lin; Provincial Chutung HospitalC.-H. Lo; Provincial Potzu Hospital - Y.-Y. Kuo; Kaobsu Health Center, Pingtung County - C.-T. Lee, C.-C. Chen; and Paihsa Health Center, Penghu County - Y.-C. Ou, W.-C. How.

\section{REFERENCES}

1. Chu CM, Liaw YF. Natural history of chronic hepatitis B virus infection: an immunopathological study. J Gastroenterol Hepatol 1997;12:S218S222.

2. Chen DS. From hepatitis to hepatoma: lessons from type B viral hepatitis. Science 1993;262:369-70.

3. IARC monographs on the evaluation of carcinogenic risks to humans. Vol. 59. Hepatitis viruses. Lyons, France: International Agency for Research on Cancer, 1994.

4. Chen CJ, Yu MW, Liaw YF. Epidemiological characteristics and risk factors of hepatocellular carcinoma. J Gastroenterol Hepatol 1997;12:S294S308.

5. Beasley RP, Hwang LY, Lin CC, Chien CS. Hepatocellular carcinoma and hepatitis B virus: a prospective study of 22707 men in Taiwan. Lancet 1981;2:1129-33.

6. Lin SM, Sheen IS, Chien RN, Chu CM, Liaw YF. Long-term beneficial effect of interferon therapy in patients with chronic hepatitis B virus infection. Hepatology 1999;29:971-5.

7. Farrell G. Hepatitis B e antigen seroconversion: effects of lamivudine alone or in combination with interferon alpha. J Med Virol 2000;61:374-9.

8. Chu CM, Liaw YF, Sheen IS, Lin DY, Huang MJ. Sex difference in chronic hepatitis B virus infection: an appraisal based on the status of hepatitis B e antigen and antibody. Hepatology 1983;3:947-50.

9. Liaw YF, Chu CM, Lin DY, Sheen IS, Yang CY, Huang MJ. Age-specific prevalence and significance of hepatitis $\mathrm{B}$ e antigen and antibody in chronic hepatitis B virus infection in Taiwan: a comparison among asymptomatic carriers, chronic hepatitis, liver cirrhosis, and hepatocellular carcinoma.

J Med Virol 1984;13:385-91.

10. Lu SN, Lin TM, Chen CJ, et al. A case-control study of primary hepatocellular carcinoma in Taiwan. Cancer 1988;62:2051-5.

11. Chen CJ, Liang KY, Chang AS, et al. Effects of hepatitis B virus, alcohol drinking, cigarette smoking and familial tendency on hepatocellular carcinoma. Hepatology 1991;13:398-406.

12. Lin TM, Chen CJ, Lu SN, et al. Hepatitis B virus e antigen and primary hepatocellular carcinoma. Anticancer Res 1991;11:2063-5.

13. Yu MW, You SL, Chang AS, Lu SN, Liaw YF, Chen CJ. Association between hepatitis $\mathrm{C}$ virus antibodies and hepatocellular carcinoma in Taiwan. Cancer Res 1991;51:5621-5.
14. Tsai JF, Jeng JE, Ho MS, et al. Additive effect modification of hepatitis $\mathrm{B}$ surface antigen and e antigen on the development of hepatocellular car cinoma. Br J Cancer 1996;73:1498-502.

15. Aalen $\mathrm{O}$. Nonparametric inference for a family of counting processes. Ann Stat 1978;6:701-26.

16. Breslow N, Crowley J. A large sample study of the life table and product limit estimates under random censorship. Ann Stat 1974;2:437-53.

17. Peña EA, Rohatgi VK. Small sample and efficiency results for the Nelson-Aalen estimator. J Stat Plann Inference 1993;37:193-202.

18. Heyward WL, Bender TR, Lanier AP, Francis DP, McMahon BJ, May nard JE. Serological markers of hepatitis B virus and alpha-fetoprotein levels preceding primary hepatocellular carcinoma in Alaskan Eskimos. Lancet 1982;2:889-91.

19. Kew MC. Hepatitis viruses and hepatocellular carcinoma. Res Virol 1998; 149:257-62

20. Chisari FV, Klopchin K, Moriyama $\mathrm{T}$, et al. Molecular pathogenesis of hepatocellular carcinoma in hepatitis B virus transgenic mice. Cell 1989; 59:1145-56

21. Wang JC. DNA topoisomerases. Annu Rev Biochem $1985 ; 54: 665-97$. 22. Freeman BA, Crapo JD. Biology of disease: free radicals and tissue injury. Lab Invest 1982;47:412-26.

23. Shafritz DA, Kew MC. Identification of integrated hepatitis B virus DNA sequences in human hepatocellular carcinoma. Hepatology 1981;1: $1-8$.

24. Matsubara $K$, Tokino $T$. Integration of hepatitis $B$ virus DNA and its implications for hepatocarcinogenesis. Mol Biol Med 1990;7:243-60.

25. Popper H, Roth L, Purcell RH, Tennant BC, Gerin JL. Hepatocarcinogenicity of the woodchuck hepatitis virus. Proc Natl Acad Sci U S A 1987;84:866-70.

26. Kim CM, Koike K, Saito I, Miyamura T, Jay G. HBx gene of hepatitis B virus induces liver cancer in transgenic mice. Nature 1991;351:31720 .

27. Paterlini P, Poussin K, Kew MC, Franco D, Brechot C. Selective accumulation of the $\mathrm{X}$ transcript of hepatitis $\mathrm{B}$ virus in patients negative for hepatitis B surface antigen with hepatocellular carcinoma. Hepatology 1995;21:313-21.

28. Henkler FF, Koshy R. Hepatitis B virus transcriptional activators: mechanisms and possible role in oncogenesis. J Viral Hepat 1996;3:109. 21.

29. Feitelson MA, Zhu M, Duan LX, London WT. Hepatitis B x antigen and p53 are associated in vitro and in liver tissues from patients with primary hepatocellular carcinoma. Oncogene 1993;8:1109-17.

30. Wang XW, Gibson MK, Vermeulen W, et al. Abrogation of p53induced apoptosis by the hepatitis B virus X gene. Cancer Res 1995;55: 6012-6.

31. Niederau C, Heintges T, Lange S, et al. Long-term follow-up of HBeAg-positive patients treated with interferon alfa for chronic hepatitis B. N Engl J Med 1996;334:1422-7.

Copyright @ 2002 Massachusetts Medical Society. 